\title{
THE SURFACE OF VENUS AS REVEALED BY VENERA 9 AND 10 PROBES
}

\author{
C.P. FLORENSKY \\ V.I. Vernadsky Institute of Geochemistry \\ and \\ Analythical Chemistry USSR Academy of Sciences \\ Moscow, USSR
}

The landers Venera 9 and 10 transmitted to Earth television pictures of the immediate vicinities of landing sites. The pictures were taken by optical-mechanical panoramic cameras looking from view-ports at about 0,9 meter above the ground. The nominal field of view is $40^{\circ} \times 180^{\circ}$. The width of one element of the picture (camera resolution) is 21 minutes of arc. The pictures were subsequently treated by computer enhancement. The first results of panorama analysis were published elsewhere $(1,4)$.

Venera 9 landed at the point $32^{\circ} \mathrm{N}, 291^{\circ} \mathrm{E}$ on the rather steep $\left(220^{\circ}\right)$ slope covered by angular sharp-edged rock fragments. The fragments have a horizontal dimension of up to 50 or $70 \mathrm{~cm}$, and a vertical dimension of no more than 15 to $20 \mathrm{~cm}$. Some of the fragments demonstrate the evidence of layering approximately parallel to the flattening of fragments. The surface between fragments is darker than the fragment surfaces of the same orientation and seems to be composed mainly of particles of a size less than the resolution of the camera. lihe on-board gamma-spectrometer reveals that the radioactivity of the surface at Venera 9 site is similar to radioactivity of basaltic rocks of the Earth ( 2 ).

Venera 10 landed at the point $16{ }^{\circ} \mathrm{N}, 291^{\circ} \mathrm{E}$ on a plain-like terrain. At the vicinity of the landing site the surface is composed of a rather dark and fine matrix (similar to the inter-fragment material of venera 9 site) protruded by the hard-rock outcrops having dimensions of up to several meters in diameter and no more than several dozens of centimeters in height. The outcrops show evidence of layering with the subhorizontal orientation. The outcrop surfaces are covered by spots which are darker than the unspotted parts of the outcrops and give the impression of a pitted surface. The outcrops have some straight fractures also. The radioactivity of surface at the Venera 10 site is also similar to terrestrial basaltic rocks and the density of outcrop- 
-forming fock $\left(2,8 \pm 0,1 \mathrm{~g} / \mathrm{cm}^{3}\right)$ is characteristic for crystalline rock $(2,3)$.

So the landing on Venus at two different sites have revealed two different types of landscapes. The presence of steep slope covered by sharp-edged fragments is evidence of the geological "juvenance" of the landscape of Venera 9 site. Plain-like character of the terrain as well as the traces of surface destruction of outcropping rocks is evidence of the "maturity" of the Venera 10 site landscape. The presence of fine together with coarse fragments and outcrops give the evidence of surface reworking processes.

If surface reworking cycles from tectonically juvenated terrains to exogeneously matured ones are typical for the Venus surface it may mean that the geologic life of Venus is more or less active. The surface reworking is difficult to understand without the adoption of rather extensive chemical surface transformations. The thermodynamical estimates show that the basaltic matter of the Venus crust and the carbon dioxide atmosphere containing about $\mathrm{O}, 1$ per cent vol of $\mathrm{H}_{2} \mathrm{O}$ could react with the formation of calcite $\mathrm{CaCO}_{3}$ and the hydrated silicates with OH-groups $\leqslant 2$.

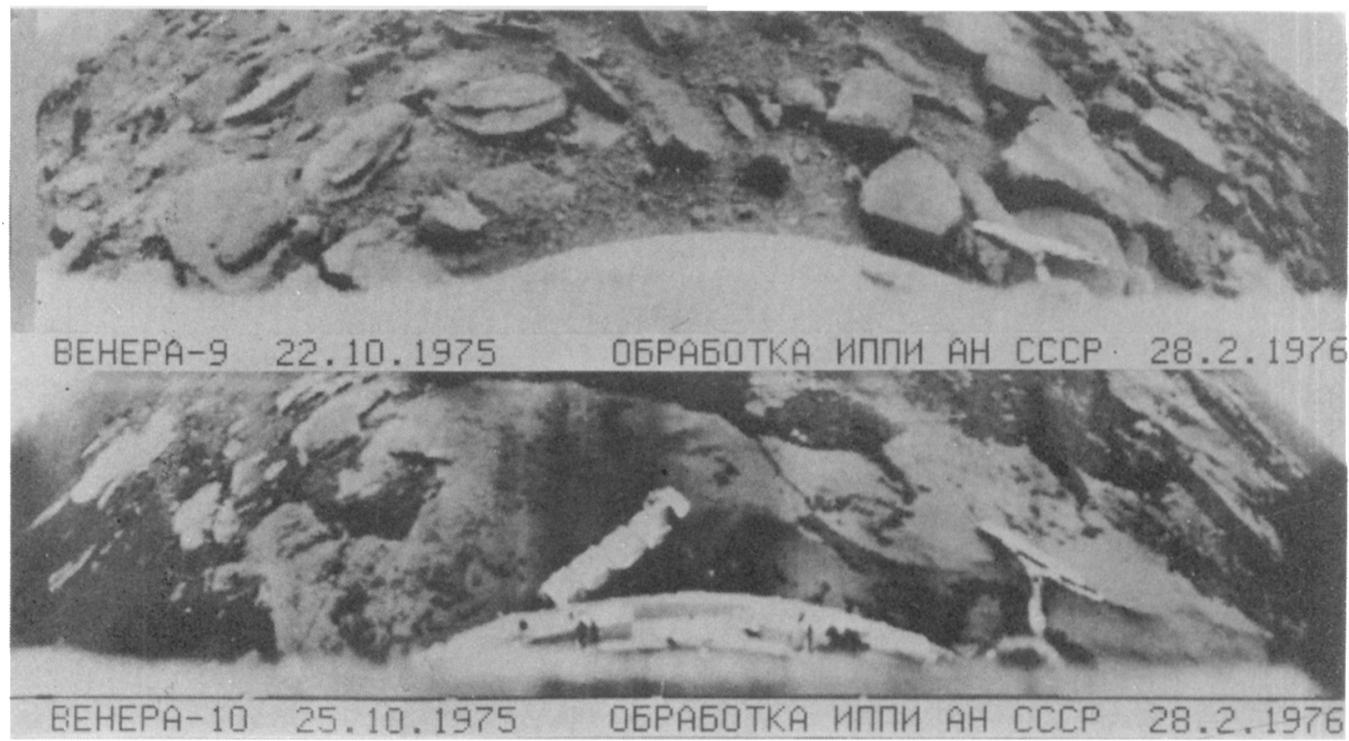

Fig. 1. Venera 9 (above) and Venera 10 (below) panoramic television pictures. The pictures were computer enhanced at the Institute on Problems of Information Transmission. 
REFERENCES

FLORENSKY C.P., BASILEVSKY A.T., ZASETSKY V.V., TRAKHMAN A.M., 1976, First panoramas of Venus. Priroda (Nature), n.8, p. 16-2l, (in Russian).

SURKOV Yu.A., KIRNOZOV F.F., GLAZOV V.N., DUNCHENKO A.G., TATZIY L.P., 1976, The abundance of natural radionuclides at Venusian rocks from the date of Venera 9 and 10. Kosmicheskie issledovania, 14 , p.5, 704-709 (in Russian).

SURKOV Ju.A., KIRNOZOV F.F., KHRISTIANOV V. K., KORCHUGANOV B.N., GLAZZOV V. N., IVANOV V.F.,

1976, The density of the rocks of Venus surface from the data of

Venus 10. Kosmicheskie issledovania, 14, n.5,697-703, (in Russian). VINOGRADOV A.P., FLORENSKY C.P., BASILEVSKY A.T., SELIVANOV A.S., 1976, First panoramas of Venus surface (preliminary analysis of pictures), USSR Akad.Nauk Doklady, 228, n. 3, pp 570-573, (in Russian). 